\title{
The Effect of Mobile-Facilitated Concept-Mapping Vocabulary Learning Strategy on EFL Learners' Vocabulary Learning and Retention
}

\author{
Parisa Yeganehpour ${ }^{1, *}$, Elham Zarfsaz ${ }^{2}$ \\ ${ }^{1}$ School of Foreign Languages, Agri Ibrahim Cecen University, Agri, Turkey \\ ${ }^{2}$ Department of Foreign Languages, Urmia Branch, Islamic Azad University, Urmia, Iran
}

Received December 23, 2020; Revised February 18, 2021; Accepted March 12, 2021

\section{Cite This Paper in the following Citation Styles}

(a): [1] Parisa Yeganehpour, Elham Zarfsaz, "The Effect of Mobile-Facilitated Concept-Mapping Vocabulary Learning Strategy on EFL Learners' Vocabulary Learning and Retention," Universal Journal of Educational Research, Vol. 9, No. 3, pp. 621 - 629, 2021. DOI: 10.13189/ujer.2021.090321.

(b): Parisa Yeganehpour, Elham Zarfsaz (2021). The Effect of Mobile-Facilitated Concept-Mapping Vocabulary Learning Strategy on EFL Learners' Vocabulary Learning and Retention. Universal Journal of Educational Research, 9(3), 621 - 629. DOI: 10.13189/ujer.2021.090321.

Copyright $\bigcirc 2021$ by authors, all rights reserved. Authors agree that this article remains permanently open access under the terms of the Creative Commons Attribution License 4.0 International License

\begin{abstract}
Due to the major role of vocabulary acquisition in language learning and challenges attributed to mastering this skill, the present study aimed at investigating the effect of mobile-facilitated concept-mapping vocabulary learning strategy on EFL learners' vocabulary learning and retention. By exploring the effect of mobile-facilitated concept-mapping vocabulary learning strategy on EFL learners' vocabulary learning and retention the present quasi-experimental study aims not only to enrich the body of literature, but also hopes to peruse its major significance by equipping EFL learners with effective strategies, such as concept mapping, to develop their vocabulary knowledge through modern technologies, such as SMS system of mobile phones. Moving toward the objectives of this study, 48 female learners participated as the treatment and control groups. The relationships among the vocabulary concepts were created in the form of concept map diagrams and sent to the participants in treatment group through Telegram. However, the participants of the control group received the vocabulary items in a way that they could not recognize the semantic relationship between them. Statistical analysis of data highlighted the realistic role of technology in language learning and revealed that the treatment group outperformed the control one in the performance of vocabulary learning and retention. According to the results, mobile-assisted concept-mapping strategy can be used as
\end{abstract}

an innovative and effective technique in instructing vocabulary for EFL learners.

Keywords Concept-Mapping, Vocabulary Learning, Retention, MLAA

\section{Introduction}

One of the crucial elements of any language used for communicating fluently is vocabulary; therefore, there are abundant studies investigating the methods, approaches, techniques and strategies which can help students acquire vocabulary knowledge [1]. Sorbi [2] claims that mastering a foreign language equals with mastering the vocabulary of that language. Unquestionably, vocabulary knowledge plays a vital role in communicative competence [3]. Moreover, it is asserted by [4] inadequate word stuck of the students cause complexity language learning.

Since 1970s, vocabulary acquisition strategies enhanced vocabulary learning and retention and facilitated instructions have gained significant attention [5]. These strategies can also provide helpful insights about students' ideas about the usefulness and value of these strategies [6]. Among the vocabulary learning strategies, concept mapping has attracted the attention of many researchers for 
which they have conducted many studies ([7], [8], [9]).

Concept mapping which is a visual way of representing knowledge was first proposed by Joseph Novak and his colleagues in the 1970 , for teaching science. In later years, concept mapping entered other areas of education. According to Wang, Lee and Chu [10], the major aspect of this strategy is its ranking construction in which concepts are put in boxes connected to each other by lines that show how a particular concept is related to other concepts. Novak and Canas [9] also claim that linking words with lines show major relationships, statements, and propositions.

Generally, the growing popularity and development of mobile technology have provided potential advantages of mobile devices for learning second/foreign language. The mobile technology not only has provided valuable resources for learners, but also supported learning with their multimedia capabilities, portability, connectivity, and flexibility. These advantages entail conducting various research studies on the efficacy of mobile technology in language learning area [11]. Cummins [11] also asserts that by encouraging the language learners to use mobile technology, "language can be used to amplify students' intellectual, aesthetic, and social identities" (p. 544).

Among the skills needed to master a language, vocabulary acquisition is considered by many researchers ( [12], [13], [14], [15]) to be one of the key areas in language learning. The reason is related to the fact that adequate vocabulary knowledge is a prerequisite for acquiring other skills such as grammatical competence, ability to communicate, listening and reading comprehension ability ( [16], [17] ); in addition, learning vocabulary can lead to high level of proficiency in the target language [18]. Meara [19] claims that acquiring sufficient vocabulary knowledge particularly in early stages of language learning is highly problematic for L2 learners. Farghal and Obiedat [20] also claim that vocabulary is neglected in most foreign language classes due to the fact that in most language classes grammar and pronunciation are at the core of language learning.

Considering the major function of vocabulary acquisition and the challenges attributed to the process of acquisition, developing approaches which can assist language learners is claimed to be of great importance by researchers namely [21]and[22]. According to [23], developing vocabulary learning strategy by researchers and instructors which can facilitate the process of vocabulary acquisition is highly important. These strategies can help language learners in acquiring, storing and retrieving information [24].

One of the new strategies rooted in Ausubel's meaningful learning is concept mapping which is "a tool for representing the interrelationships among concepts in an integrated, hierarchical manner" [25](p. 249). According to Ausubel (1968, as cited in [26]), meaningful learning takes place when learners relate previously learnt materials into one's new information in their cognitive structure. [27] assert that connecting concept mapping and technology provides a visual and novel approach to learning. Without learning vocabulary strategies such as concept mapping, the learners cannot regulate their own learning nor find the relationships among the learned concepts. Thus, meaningful learning in which learners connect the already learnt materials into new information in their cognitive structure never occurs.

Through providing visual representation of concepts and relationships among them, concept maps can be used as metacognitive tools which assist learners to think reflectively [28], [29]. According to [30] (p. 2), "pictorial language of thinking, such as concept maps, is advantageous in that they enable students to simplify complex patterns of ideas and minimize the load of information students must hold in their memories". [31], [32] argued that combining unfamiliar lexis with visual aids could aid vocabulary learning.

"Through concept mapping learners are able to externalize their existing knowledge and combine it with new knowledge rearranging and internalizing both the old and new knowledge in a graphic form" (Wu, Hwang, Milrad, Ke, \& Huang, 2012as cited in [33]). They can also be employed by teachers to help learners talk about complex ideas which can lead to collaborative learning and used to assess and evaluate the performance of learners [9]. In general, any language learning strategy including concept mapping is claimed by [34] to develop students' autonomy and language learning abilities.

Technologies such as mobile which are accessible to learners at anytime and anywhere facilitate the process of learning and promote the chances of situated learning [35]. In the same scope, [36] and [37] in their study concluded that techno-visual aids had a positive effect on L2 vocabulary learning.

The present study aims to develop EFL learners' vocabulary knowledge with effective strategies such as concept mapping, and assist them to easily access this knowledge through modern technologies such as SMS system of mobile phones.

\section{Methodology}

The study explored the influence of mobile-facilitated concept-mapping vocabulary learning strategy on EFL learners' vocabulary learning and retention. Therefore, learners' vocabulary learning and retention were considered as the dependent variable and mobile-facilitated concept-mapping strategy as the independent variable.

\subsection{Participants}

This quasi-treatment research was put into practice with 48 students in two intact Prep classes at Foreign Language school of Agri, Turkey. Their age ranged from 17 to 26 years old. Furthermore, all subjects did not have any prior experience in concept-mapping strategy training. One of 
the two intact classes was randomly assigned to a mobile-facilitated concept mapping group and the other one as a control one.

\subsection{Procedure}

For selecting the participants of this study, two intact English classes including 54 students were selected randomly among prep classes. Although, the participants have taken a placement test, for more assurance, and to check the homogeneity of participants again the Nelson English language proficiency was applied. All the 54 participated students were taken the Nelson proficiency test for the purpose of homogenizing them and omitting outliers. After removing 6 outliers, the rest of participants were divided into two groups: a control group $(\mathrm{N}=25)$ and a treatment group $(\mathrm{N}=23)$.

After choosing the lists of vocabulary from Top Notch book series (3B) [37] for creating the concept maps, they were prepared for participants of the treatment group in the form of a diagram to show the relationships among the concepts. Afterwards, the concept maps were sent to the participants of the treatment group through Telegram.

Mobile phones were used by the researcher and the participants for sending and receiving vocabulary. All the participants were required to install Telegram to receive the materials. While vocabularies were presented in the form of concept maps to the students in the treatment group prior to the instruction in the class, the control group received the definition of the same vocabulary prior to the instruction. All the vocabulary that were going to be taught in one session to the participants of the treatment, were in the form of concept maps and mainly used for the purpose of understanding the relationship between the words. However, the participants of the control group received the vocabulary that were going to be taught in one session during three phases, in an order that they could not recognize semantic relationship between them.
A vocabulary test containing 30 vocabulary questions (10 questions in multiple-choice format, 10 matching test questions and 10 cloze test questions) was prepared by the researcher based on the list of vocabulary used in the treatment. After piloting and omitting the malfunctioning questions, the test was applied initially as the pre-test before the treatment and later as the post-test immediately after the treatment, and as delayed post-test, three weeks after the post-test was administered.

\section{Data Analysis}

For analyzing the data, two paired t-tests were performed on the pre-test, post-test and delayed post-test scores. Finally, three independent t-tests were performed on post-test and delayed post-test scores to spot the superiority of inferiority of treatment group in comparison to the control one.

Prior to the main phase of the study, in order to reach a homogenous group of participants, the Nelson homogeneity test result was analyzed to spot the outliers. Table 1 shows the descriptive statistics of the scores obtained by the participants in the homogeneity test.

Based on the mean score (32.07) and standard deviation (3.04) on the Nelson proficiency test, 48 learners out of 54 were selected as the participants of the study.

In order to check the vocabulary proficiency of the participants in two groups, a pre-test was given to them. However, prior to analyzing the data obtained from pre-test, Kolmogorov-Smirnov test was applied on the results of the pre-test scores, to check whether the data was normally distributed.

Table 2 reveals the normal distribution of the scores obtained from pre-test. The significance level $(\mathrm{p}=.07)$ was more than the set alpha level (.05), indicating that the scores were normally distributed. Accordingly, the researchers decided to applyparametric statistics.

Table 1. Scores Obtained by Study Population in Homogeneity Test

\begin{tabular}{|c|c|c|c|c|c|c|c|}
\hline & $\mathrm{N}$ & Minimum & Maximum & \multicolumn{2}{|c|}{ Mean } & Std. Deviation & Variance \\
\hline & Statistic & Statistic & Statistic & Statistic & Std. Error & Statistic & Statistic \\
\hline Proficiency Test & 54 & 23 & 42 & 32.07 & .414 & 3.040 & 9.240 \\
\hline Valid N (listwise) & 54 & & & & & & \\
\hline
\end{tabular}

Table 2. The Normality of Distribution of Data Obtained Pre-test

\begin{tabular}{|c|c|c|}
\hline & & Pre-test \\
\hline \multicolumn{2}{|c|}{$\mathrm{N}$} & 48 \\
\hline \multirow{2}{*}{ Normal Parameters ${ }^{\mathrm{a}, \mathrm{b}}$} & Mean & 12.98 \\
\hline & Std. Deviation & 1.744 \\
\hline \multirow{3}{*}{ Most Extreme Differences } & Absolute & .125 \\
\hline & Positive & .125 \\
\hline & Negative & -.141 \\
\hline \multicolumn{2}{|c|}{ Test Statistic } & .125 \\
\hline \multicolumn{2}{|c|}{ Asymp. Sig. (2-tailed) } & $.071^{\mathrm{c}}$ \\
\hline
\end{tabular}


In order to check any significant difference among the performances of the participants in groups prior to the treatment, an independent sample t-test was implemented.

Table 3. Descriptive Statistics of the Data Obtained from the Pre-test

\begin{tabular}{|c|c|c|c|c|c|}
\hline & Grouping & $\mathrm{N}$ & Mean & $\begin{array}{c}\text { Std. } \\
\text { Deviation }\end{array}$ & $\begin{array}{c}\text { Std. Error } \\
\text { Mean }\end{array}$ \\
\hline \multirow{2}{*}{$\begin{array}{c}\text { Pre- } \\
\text { test }\end{array}$} & Treatment & 23 & 12.83 & 1.337 & .279 \\
\cline { 2 - 6 } & Control & 25 & 13.12 & 2.068 & .414 \\
\hline
\end{tabular}

The mean score and standard deviation of the related groups in the pre-test were $\mathrm{M}=12.83, \mathrm{SD}=1.33$ and $\mathrm{M}=$ $13.12, \mathrm{SD}=2.06$. According to the mean scores, it seems that the control group has got higher vocabulary proficiency in comparison with the treatment one (table 3.3).

The obtained results of independent samples t-test were applied on the pre-test scores of the groups to check any possible difference among groups regarding vocabulary proficiency (table 4).

Based on the inspection of the results obtained in relation to the Table $5[\mathrm{~T}(46)=.57, \mathrm{P}=0.55]$, there was not any statistically significant difference between the two groups vocabulary proficiency at the $\mathrm{p}<.05$ level in pre-test scores. Getting assured of the participants' vocabulary knowledge homogeneity, finally a vocabulary post-test was given to the students of both groups to measure their immediate vocabulary learning and compare it to the initial vocabulary knowledge.

Similar to the pre-test, first of all, Kolmogorov-Smirnov test was implemented on the data taken from the post-test scores, to check whether the data is normally distributed or not.

Table 5 demonstrates normality distribution of the scores obtained from post-test. The level of significance ( $\mathrm{p}$ $=.1$ ) was more than the set alpha (0.05), indicating that the scores were normally distributed. To find any significant effect of mobile-facilitated concept-mapping strategy on EFL learners' vocabulary learning and answer the first research question, a paired samples t-test was applied on the pre-test and post-test scores of the participants to check whether there was a progress in vocabulary learning and knowledge. The results are shown in Tables 6 and 7.

Table 4. Analysis of Variances of the Pre-test Scores of both Groups

\begin{tabular}{|c|c|c|c|c|c|c|c|c|c|c|}
\hline & \multicolumn{2}{|c|}{$\begin{array}{c}\text { Levene's Test for } \\
\text { Equality of } \\
\text { Variances } \\
\end{array}$} & \multicolumn{7}{|c|}{ t-test for Equality of Means } \\
\hline & & \multirow[t]{2}{*}{$\mathrm{F}$} & \multirow[t]{2}{*}{ Sig. } & \multirow[t]{2}{*}{$\mathrm{t}$} & \multirow[t]{2}{*}{ df } & \multirow[t]{2}{*}{$\begin{array}{c}\text { Sig. } \\
\text { (2-tailed) }\end{array}$} & \multirow[t]{2}{*}{$\begin{array}{c}\text { Mean } \\
\text { Difference }\end{array}$} & \multirow[t]{2}{*}{$\begin{array}{l}\text { Std. Error } \\
\text { Difference }\end{array}$} & \multicolumn{2}{|c|}{$\begin{array}{l}\text { 95\% Confidence } \\
\text { Interval of the } \\
\text { Difference }\end{array}$} \\
\hline & & & & & & & & & Lower & Upper \\
\hline \multirow{2}{*}{ Pre-test } & $\begin{array}{c}\text { Equal } \\
\text { variances } \\
\text { assumed }\end{array}$ & 1.886 & .176 & -.579 & 46 & .565 & -.294 & .508 & -1.316 & .728 \\
\hline & $\begin{array}{c}\text { Equal } \\
\text { variances } \\
\text { not assumed }\end{array}$ & & & -.589 & 41.426 & .559 & -.294 & .499 & -1.301 & .713 \\
\hline
\end{tabular}

Table 5. The Normality of Distribution of Data Obtained in Post-test

\begin{tabular}{|c|c|c|}
\hline & & Post-test \\
\hline \multicolumn{2}{|c|}{$\mathrm{N}$} & 48 \\
\hline \multirow{2}{*}{ Normal Parameters ${ }^{\mathrm{a}, \mathrm{b}}$} & Mean & 18.29 \\
\hline & Std. Deviation & 3.358 \\
\hline \multirow{3}{*}{ Most Extreme Differences } & Absolute & .129 \\
\hline & Positive & .229 \\
\hline & Negative & -.101 \\
\hline \multicolumn{2}{|c|}{ Test Statistic } & .129 \\
\hline \multicolumn{2}{|c|}{ Asymp. Sig. (2-tailed) } & $.101 \mathrm{c}$ \\
\hline
\end{tabular}


Table 6. Score Obtained in the Pre-test and Post-test

\begin{tabular}{|c|c|c|c|c|c|}
\hline & & Mean & $\mathrm{N}$ & $\begin{array}{c}\text { Std. } \\
\text { Deviation }\end{array}$ & $\begin{array}{c}\text { Std. } \\
\text { Error } \\
\text { Mean }\end{array}$ \\
\hline \multirow{2}{*}{$\begin{array}{c}\text { Pair } \\
1\end{array}$} & Pre-test-treatment & 12.83 & 23 & 1.337 & .279 \\
\cline { 2 - 6 } & Post-test-treatment & 19.57 & 23 & 4.251 & .886 \\
\hline
\end{tabular}

As it is shown in the Table 6, the mean score and standard deviation of the Pre-test and Post-test of treatment group who were taught using mobile facilitated concept-mapping vocabulary learning strategy were $\mathrm{M}=$ $12.83, \mathrm{SD}=1.33$ and $\mathrm{M}=19.57, \mathrm{SD}=4.25$ respectively. The results showed a considerably large difference among the mean scores which signal a considerable progress in vocabulary proficiency and learning of the participants immediately after the treatment phase. Hence, a paired samples t-test checked the significant difference. Table 7 reveals the results of t-test applied on the data.

Based on the statistics revealed in the table $7 \mathrm{t}(22)=8.52$, $\mathrm{P}=0.00$, there was a statistically significant difference at the $\mathrm{p}<.05$ level comparing the pre and post-test scores of treatment group. As a matter of fact, proving the statistical significance of the observed difference, the study's first hypothesis was approved. However, the researcher in further investigation of the results compared the performances of control and treatment groups in immediate post-test after treatment to check the whether the under study strategy has outperformed the traditional common one or not. To do so, the researcher applied an independent t-test on the post-test scores of groups. Tables 8 and 9 revealed the findings.

According to table 2, the mean scores for vocabulary test were $M=19.57$ and $M=17.12$ for treatment and control groups respectively. A quick glance at the scores revealed that the strategy under study, i.e., mobile-facilitated concept-mapping vocabulary learning strategy has improved participants' vocabulary proficiency better. So, an independent samples t-test checked the formed hypothesis.

Table 7. Paired Samples t-test after the Immediate Post-test Comparing the Performances in Pre and Post-test

\begin{tabular}{|c|c|c|c|c|c|c|c|c|c|}
\hline & & \multicolumn{5}{|c|}{ Paired Differences } & \multirow{3}{*}{$\mathrm{t}$} & \multirow{3}{*}{ df } & \multirow{3}{*}{$\begin{array}{c}\text { Sig. } \\
\text { (2-tailed) }\end{array}$} \\
\hline & & \multirow{2}{*}{ Mean } & \multirow{2}{*}{$\begin{array}{c}\text { Std. } \\
\text { Deviation }\end{array}$} & \multirow{2}{*}{$\begin{array}{l}\text { Std. } \\
\text { Error } \\
\text { Mean }\end{array}$} & \multicolumn{2}{|c|}{$\begin{array}{c}95 \% \text { Confidence Interval } \\
\text { of the Difference }\end{array}$} & & & \\
\hline & & & & & Lower & Upper & & & \\
\hline Pair 1 & $\begin{array}{l}\text { Pre-test-treatment - } \\
\text { Post-test-treatment }\end{array}$ & -6.739 & 3.793 & .791 & -8.379 & -5.099 & -8.522 & 22 & .000 \\
\hline
\end{tabular}

Table 8. Immediate Post-test Scores of Treatment and Control Groups

\begin{tabular}{|c|c|c|c|c|c|}
\hline & Grouping & N & Mean & Std. Deviation & Std. Error Mean \\
\hline \multirow{3}{*}{ Post- test } & Treatment & 23 & 19.57 & 4.251 & .886 \\
\cline { 2 - 6 } & Control & 25 & 17.12 & 1.590 \\
\hline
\end{tabular}

Table 9. An Independent Samples t-test Comparing the Immediate Post-test Scores of Treatment and Control Groups

\begin{tabular}{|c|c|c|c|c|c|c|c|c|c|c|}
\hline & \multicolumn{2}{|c|}{$\begin{array}{c}\text { Levene's Test for } \\
\text { Equality of Variances }\end{array}$} & \multicolumn{7}{|c|}{ t-test for Equality of Means } \\
\hline & & \multirow[t]{2}{*}{$\mathrm{F}$} & \multirow[t]{2}{*}{ Sig. } & \multirow[t]{2}{*}{$\mathrm{t}$} & \multirow[t]{2}{*}{ df } & \multirow[t]{2}{*}{$\begin{array}{c}\text { Sig. } \\
\text { (2-tailed) }\end{array}$} & \multirow[t]{2}{*}{$\begin{array}{c}\text { Mean } \\
\text { Difference }\end{array}$} & \multirow[t]{2}{*}{$\begin{array}{l}\text { Std. Error } \\
\text { Difference }\end{array}$} & \multicolumn{2}{|c|}{$\begin{array}{c}95 \% \text { Confidence } \\
\text { Interval of the } \\
\text { Difference }\end{array}$} \\
\hline & & & & & & & & & Lower & Upper \\
\hline \multirow[b]{2}{*}{ Post-test } & $\begin{array}{c}\text { Equal } \\
\text { variances } \\
\text { assumed } \\
\end{array}$ & 14.267 & .000 & 2.681 & 46 & .010 & 2.445 & .912 & .610 & 4.281 \\
\hline & $\begin{array}{c}\text { Equal } \\
\text { variances } \\
\text { not } \\
\text { assumed }\end{array}$ & & & 2.596 & 27.604 & .015 & 2.445 & .942 & .515 & 4.376 \\
\hline
\end{tabular}


The findings of the independent t-test analyzing the mean differences in Table 9 reveals that the difference among the groups $(\mathrm{p}=0.01)$ is statistically significant because the $\mathrm{p}$-value is less than the set alpha (0.05). It can be concluded that the groups are different in post-test and treatment group had been superior than the control one. The next section of the data analysis of current chapter deals with investigating the data related to the second research question, which aimed at finding whether using mobile-facilitated concept-mapping vocabulary learning strategy has any significant effect on EFL learners' vocabulary retention after three weeks. As was done for the previous sets of scores, another Kolmogorov-Smirnov test was to get assured of the distribution normality.

Table 10. The Normality of Distribution of Data Obtained in Delayed Post-test

\begin{tabular}{|c|c|c|}
\hline \multicolumn{2}{|c|}{} & Delayed Post-test \\
\hline \multirow{2}{*}{ Normal Parameters $^{\mathrm{a}, \mathrm{b}}$} & $\mathrm{N}$ & 48 \\
\cline { 2 - 3 } & Mean & 16.88 \\
\hline \multirow{3}{*}{$\begin{array}{c}\text { Most Extreme } \\
\text { Differences }\end{array}$} & Absolute & 3.226 \\
\cline { 2 - 3 } & Positive & .114 \\
\cline { 2 - 3 } & Negative & -.114 \\
\hline \multicolumn{2}{|c|}{ Test Statistic } & .114 \\
\hline \multicolumn{2}{|c|}{ Asymp. Sig. (2-tailed) } & $.090^{\mathrm{c}}$ \\
\hline
\end{tabular}

Table 10 reveals the normal distribution of the scores obtained from delayed post-test. The significance level ( $\mathrm{p}$ $=.09)$ was more than the set alpha level (0.05), indicating that the scores were normally distributed. Accordingly, the researchers decided toapplyparametric statistics.

To address the second research question and to check the retention of vocabulary items learned by all students and also to examine the efficacy of the given treatments a delayed post-test was given to both groups.

Table 11. Score Obtained by in the Pre-test and Delayed Post-test

\begin{tabular}{|c|c|c|c|c|c|}
\hline & Mean & $\mathrm{N}$ & $\begin{array}{c}\text { Std. } \\
\text { Deviation }\end{array}$ & $\begin{array}{c}\text { Std. } \\
\text { Error } \\
\text { Mean }\end{array}$ \\
\hline \multirow{3}{*}{ Pair 1 } & $\begin{array}{c}\text { Pre-test- } \\
\text { treatment }\end{array}$ & 12.83 & 23 & 1.337 & .279 \\
\cline { 2 - 6 } & $\begin{array}{c}\text { Delayed- } \\
\text { treatment }\end{array}$ & 18.48 & 23 & 3.752 & .782 \\
\hline
\end{tabular}

As table 11 shows, the pre and delayed post-tests' mean and standard deviation were $\mathrm{M}=12.83, \mathrm{SD}=1.33$ and $\mathrm{M}=$ $18.48, \mathrm{SD}=3.75$ respectively. In order to ensure that the observed difference among groups was significant, a paired samples t-test was used.

According to the statistics depicted in the table 12, $\mathrm{t}(22)$ $=7.00, \mathrm{P}=0.00$, there was a statistically significant difference at the $\mathrm{p}<.05$ level. Hence, it was concluded that the second hypothesis of this study was accepted. In addition, similar to the further investigation done on post-test scores, the researcher compared the performances of control and treatment groups in delayed post-test given three weeks after treatment to check whether the mobile-facilitated concept-mapping vocabulary learning strategy has outperformed the traditional one or not. An independent t-test on the post-test scores of groups shows the findings.

Table 13 compares the performances of groups in delayed post-tests. The mean scores equals $\mathrm{M}=18.48$ and $\mathrm{M}=15.40$ for treatment and control groups respectively. The difference between the mean scores shows that performance of treatment group was superior to the control group. The independent samples t-test wasapplied on the scores to examine the significance of difference.

Table 12. Paired Samples t-test Applied on the Scores after the Immediate Post-test Comparing the Performances in Pre and Post-test

\begin{tabular}{|c|c|c|c|c|c|c|c|c|c|}
\hline & & \multicolumn{5}{|c|}{ Paired Differences } & \multirow{3}{*}{$\mathrm{t}$} & \multirow{3}{*}{ df } & \multirow{3}{*}{$\begin{array}{c}\text { Sig. } \\
\text { (2-tailed) }\end{array}$} \\
\hline & & \multirow[t]{2}{*}{ Mean } & \multirow[t]{2}{*}{$\begin{array}{c}\text { Std. } \\
\text { Deviation }\end{array}$} & \multirow{2}{*}{$\begin{array}{l}\text { Std. } \\
\text { Error } \\
\text { Mean }\end{array}$} & \multicolumn{2}{|c|}{$\begin{array}{l}95 \% \text { Confidence } \\
\text { Interval of the } \\
\text { Difference }\end{array}$} & & & \\
\hline & & & & & Lower & Upper & & & \\
\hline Pair 1 & $\begin{array}{l}\text { Pre-test-treatment } \\
\text {-Delayed-treatment }\end{array}$ & -5.652 & 3.868 & .807 & -7.325 & -3.979 & -7.007 & 22 & .000 \\
\hline
\end{tabular}

Table 13. Delayed Post-test Scores of Treatment and Control Groups

\begin{tabular}{|l|c|c|c|c|c|}
\hline & Grouping & N & Mean & Std. Deviation & Std. Error Mean \\
\hline \multirow{3}{*}{ Delayed Post-test } & Treatment & 23 & 18.48 & 3.752 & .782 \\
\cline { 2 - 6 } & Control & 25 & 15.40 & 1.658 & .332 \\
\hline
\end{tabular}


Table 14. An Independent Samples t-test Comparing the Delayed Post-test Scores of Treatment and Control Groups

\begin{tabular}{|c|c|c|c|c|c|c|c|c|c|c|}
\hline & \multicolumn{2}{|c|}{$\begin{array}{l}\text { Levene's Test for } \\
\text { Equality of } \\
\text { Variances } \\
\end{array}$} & \multicolumn{7}{|c|}{ t-test for Equality of Means } \\
\hline & & \multirow[t]{2}{*}{$\mathrm{F}$} & \multirow[t]{2}{*}{ Sig. } & \multirow[t]{2}{*}{$\mathrm{t}$} & \multirow[t]{2}{*}{ df } & \multirow[t]{2}{*}{$\begin{array}{c}\text { Sig. } \\
\text { (2-tailed) }\end{array}$} & \multirow[t]{2}{*}{$\begin{array}{c}\text { Mean } \\
\text { Difference }\end{array}$} & \multirow[t]{2}{*}{$\begin{array}{l}\text { Std. Error } \\
\text { Difference }\end{array}$} & \multicolumn{2}{|c|}{$\begin{array}{l}95 \% \text { Confidence } \\
\text { Interval of the } \\
\text { Difference }\end{array}$} \\
\hline & & & & & & & & & Lower & Upper \\
\hline \multirow{2}{*}{$\begin{array}{l}\text { Delayed } \\
\text { Post-test }\end{array}$} & $\begin{array}{c}\text { Equal } \\
\text { variances } \\
\text { assumed } \\
\end{array}$ & 14.295 & .000 & 3.728 & 46 & .001 & 3.078 & .826 & 1.416 & 4.740 \\
\hline & $\begin{array}{c}\text { Equal } \\
\text { variances } \\
\text { not } \\
\text { assumed }\end{array}$ & & & 3.622 & 29.737 & .001 & 3.078 & .850 & 1.342 & 4.814 \\
\hline
\end{tabular}

Table 14 compares the performances of groups in delayed post-test based on the significance levels and the mean differences revealed that the treatment group outperformed the control one in delayed post-test given three weeks after the treatment.

\section{Discussion}

Regarding the importance of vocabulary acquisition which is introduced by some scholars such as [12], [13], [14] and [15] to be one of the crucial areas in second or foreign language learning, the vocabulary teaching method and medium get significantimportance. Developing approaches which can assist language learners is claimed to be of great importance by researchers such as [21] and [22].

The findings of current study proving the efficacy of mobile-assisted concept mapping can be well justified by the claims of [26], stating that when learners relate previously learnt materialsto one's new information in their cognitive structure which takes place while building concept maps. In addition, [34] assert that connecting concept mapping and technology provides a visual and novel approach to learning. Without learning vocabulary strategies such as concept mapping, the learners cannot regulate their own learning nor find the relationships among the learned concepts; thus, meaningful learning, in which learners connect the already learnt materials into new information in their cognitive structure, never occurs. Considering the mobile-facilitated feature of the concept mapping strategy, it can be claimed that it boosts the effect of mapping vocabulary learning strategy since as [35] assert technologies, such as mobile which are accessible to learners at anytime and anywhere facilitate the process of learning and promote the chances of situated learning.

The results of the current study are in line with the study carried out by [27], [26] and[28] in terms of efficacy of concept mapping.

In this line, the findings are confirmed by [27] who investigated the effect of concept mapping on Iranian intermediate EFL learners' self-efficacy and expository writing accuracy similarly based on the findings of their study the positive effect of concept mapping on self-efficacy and writing accuracy was proved. In a similar study, [26] investigated the effect of concept mapping on EFL students' meaningful learning of English reading comprehension. Close to the results of current study, the authors found that concept mapping strategy had a positive effect on English academic achievement and meaningful reading comprehension in students.

Findings of the current study regarding the efficacy of technology and mobile phones are also in line with [30] who examined the effectiveness of vocabulary learning via mobile phones. Furthermore, [31] who investigated the impact of a mobile assisted language learning (MALL) on vocabulary learning of six non-native English speaking migrant women came across similar results to this study indicating that based on the participants' responses to MALL lessons, it was revealed that MALL had positive effect on their vocabulary learning.

\section{Conclusions}

This research highlights the realistic role of technology in language learning and how technology can be combined with other techniques and strategies for the purpose of facilitating and accelerating the teaching and learning process. In a world where technology enhanced language learning and teaching is on the rise, mobile-assisted language learning is rapidly securing its place in world of language learning, mainly because of the availability of mobile phones and their attractiveness for the learners over other tools of teaching and learning a language. Using mobile phone technology has provided alternatives for people to learn and teach without limits of time and space [37].

According to the results subjects of the study in the treatment group who received concept maps that through Telegram outperformed the control group who received the same vocabulary via traditional instruction (definition of the vocabulary), again through Telegram. Therefore, it can be concluded that concept-mapping strategy can be used as an innovative technique in instructing vocabulary for EFL 
learners.

[36] claims that MALL is one of the greatest student motivating systems that can encourage students to keep in enduring touch with the language, with the teacher and with their classmates. Based on the results, it can be concluded that not only the concept mapping strategy was an effective factor in the accomplishment of the treatment group, but also the combination of technology (MALL) with this strategy can be an effective way to success. Using mobile phones in this study can be regarded as a practical and convenient medium for teaching and learning vocabulary. Therefore, when participants have to learn English words with mobile phones, offering them concept maps can help them learn better.

\section{REFERENCES}

[1] P. Khosravizadeh and S. Mollaei, "Incidental Vocabulary Learning: A Semantic Field Approach," Brain broad research in artificial intelligence and neuroscince, vol. 2 , no. 3, pp. 20-28, 2011.

[2] A. Sorbi, "The relationship among word knowledge,," International Journal of Language Studies, vol. 4, no. 1, pp. $1-28,2010$

[3] A. Bastanfar and T. Hashemi, "Vocabulary learning strategies and ELT materials. A study of the extent to which VLS research informs local coursebooks in Iran.," International Education Studies, vol. 3, no. 3, pp. 158-166, 2010 .

[4] A. \&. G. M. Asgari, "The Type of Vocabulary Learning Strategies Used by ESL Students in University Putra Malaysia," English Language Teaching, vol. 4, pp. 84-90, 2011.

[5] G. H. a. K. Abdullah, "Vocabulary Learning Strategies of Iranian Undergraduate EFL Students and its Relation to their Vocabulary Size European Journal of Social Sciences," European Journal of Social Sciences, vol. 11, no. 1, p. 39, 2009.

[6] W. S. Wu, "Use and helpfulness rankings of vocabulary learning strategies employed by EFL learners in Taiwan," Journal of Humanities and Social Sciences, vol. 1, no. 2, pp. 7-13, 2005.

[7] S.,. K. S. Sutherland, "Concept mapping methodology: A catalyst for organizational learning," Evaluation and Program Planning, vol. 28, p. 257-269, 2005.

[8] R. Pishghadam and A. Ghanizadeh, "On the impact of concept mapping as a prewriting activity on EFL learners' writing ability," IJAL, vol. 9, no. 2, pp. 1-26, 2006.

[9] J. D. Novak and A. J. Canas, The theory underlying concept maps and how to construct and use them. Technical Report IMHC., Florida Institute for Human and Machine Cognition, Pensacola: FL., 2006.

[10] W. Wang, C. Lee and C. Y. C., "A Brief Review on Developing Creative Thinking in Young Children by Mind
Mapping," International Business Research, vol. 3, no. 3, pp. 233-238, 2010.

[11] J. Cummins, Language, power, and pedagogy: Bilingual children in the crossfire, Clevedon, UK: Multilingual Matters, 2000.

[12] B. Laufer, "Second language vocabulary acquisition from language input and from form-focused activities," Language Teaching, vol. 42, no. 3, pp. 341-354, 072009.

[13] M. P. A. Llach and A. B. Gómez, "Children's characteristics in vocabulary acquisition and use in the written production," Revista Espanola de Linguistica Aplicada, vol. 20, no. 20, pp. 9-26, 2007.

[14] I. S. Nation, Learning Vocabulary in Another Language, Cambridge: Cambridge University Press, 2001.

[15] Z. M. Tavil and K. U. İşisağ, "Teaching vocabulary to very young learners," EKEV Academy Journal, vol. 13, no. 38, pp. 299-308, 2009.

[16] E. Smidt and V. Hegelheimer, "Effects of online academic lectures on ESL listening comprehension, incidental vocabulary acquisition, and strategy use," Computer Assisted Language Learning, vol. 17, p. 517-556, 2004.

[17] N. Schmitt, T. Cobb, M. Horst and D. Schmitt, "How much vocabulary is needed to use English?," Language Teaching, vol. 2, no. 50, pp. 212-226, 2017.

[18] F. Boers and S. Lindb, Cognitive Linguistic Approaches to Teaching Vocabulary and Phraseology, berlin: Walter de Grruyter GmbH \& Co.KG, 2008.

[19] P. Meara, "Vocabulary acquisition: a neglected aspect of language learning.," Language Teaching and Linguistics, vol. 13 , no. 4 , pp. 22-46, 198 .

[20] M. Farghal and H. Obiedat, "Collocations: A Neglected Variable in EFL," IRAL : International Review of Applied Linguistics in Language Teaching, vol. 33, no. 4, p. 315, 1995.

[21] I. Kojig-Sabo and .P. Lightbown, "Student's approaches to vocabulary learning and their relationship to success.," The Modern Language Journal, vol. 73, no. 2, pp. 135-149, 1999.

[22] D. A. Gilman and D. Kim, "Effects of text, audio, and graphic aids in multimedia instruction for vocabulary learning.," Educational Technology \& Society, vol. 11, no. 3, pp. 114-126, 2008.

[23] Y. Gu and R. K. Johnson, "Vocabulary learning strategies and language learning outcomes," Language Learning, vol. 46, no. 4, pp. 643-479, 1996.

[24] R. Oxford, "Language learning styles and strategies: An overview," En Learning Styles y Strategies, pp. 1-25., vol. Oxford, pp. 1-25, 2001.

[25] P. Chularut and T. KDeBacker, "The influence of concept mapping on achievement, self-regulation, and self-efficacy in students of English as a second language," Contemporary Educational Psychology, vol. 29, no. 3, pp. 248-263, 2004.

[26] M. Kalhor and G. Mehran, "The effect of concept mapping strategyoncritical thinkingskills in students," Educational Psychology, vol. 13, no. 44, pp. 153-172, 2017. 
[27] B. Nobahar, A. Nemat Tabrizi and M. Shaghaghi, "The effect of concept mapping on Iranian intermediate EFL learners' self-efficacy and expository writing accuracy," Theory and practice in language studies, vol. 3, no. 11, pp. 2117-2127, 2013.

[28] Z. Tajeddin and S. Tabatabaei, "Concept Mapping as a Reading Strategy: Does It Scaffold Comprehension and Recall?," The Reading Matrix: An International Online Journal, vol. 2016, no. 1, pp. 194-208, 2016.

[29] J. J. Mintzes, J. Wandersee, J. H. and J. Novak, Teaching science for understanding, San Diego: CA: Academic Press, 1997.

[30] J. Burston, H. Zhang and W. Song, "Reexamining the effectiveness of vocabulary learning via mobile phones," Turkish Online Journal of Educational Technology, vol. 10, no. 3, pp. 203-214, 2011.

[31] K. S. Alharthi Ahmad, F. Sudweeks and J. Armarego, "Learning English vocabulary in a Mobile Assisted Language Learning (MALL) environment: A sociocultural study of migrant women," Interdisciplinary Journal of e-Skills and Life Long Learning, vol. 11, no. 25, 2015.

[32] T. D. Terrell, " Acquisition in the Natural Approach," The
Modern Language Journal, vol. 70, no. 3, pp. 213-227, 1986.

[33] A. M. Alhomaidan, "The Effectiveness of Concept Mapping on Learning: A Study in a Saudi College-Level Context," American Journal of Educational Research, vol. 3, no. 8, pp. 1010-1014, 2015.

[34] C. Lee, "An overview of language learning strategies," ARECLS, vol. 7, pp. 132-152, 2010.

[35] G. J. Hwang, Y. Shi and H. C. Chu, "A concept map approach to developing collaborative mindtools for context-aware ubiquitous learning," British Journal of Educational Technology, vol. 42, no. 5, pp. 778-789, 2011.

[36] D. Kim ve D. A. Gilman, «Effects of Text, Audio, and Graphic Aids in Multimedia Instruction for Vocabulary Learning.,» Educational Technology \& Society, cilt 11, no. 3, pp. 114-126, 2008.

[37] M. Salaberry, "The Use of Technology for Second Language Learning and Teaching: A Retrospective," Modern Language Journal , vol. 85, no. 1, pp. 39-56, 2001.

[38] J. M. Saslow and A. Ascher, TOP NOTCH Fundamentals, SET 2nd Ed., Pearson Education, 2012. 